\title{
Morphometric Parameters and Allometric Growth in Paradise Threadfin Polynemus paradiseus (Linnaeus, 1758) from a Coastal River of Bangladesh
}

Chaklader MR ${ }^{1}$, Siddik MAB ${ }^{1 *}$, Ashfaqun Nahar ${ }^{2}$, Hanif MA' ${ }^{1}$ Alam MJ $^{3}$ and Sultan Mahmud ${ }^{4}$

${ }^{1}$ Department of Fisheries Biology and Genetics, Patuakhali Science and Technology University, Bangladesh

${ }^{2}$ Department of Marine Fisheries and Oceanography, Patuakhali Science and Technology University, Bangladesh

${ }^{3}$ Department of Fisheries Management, Patuakhali Science and Technology University, Bangladesh

${ }^{4}$ Department of Aquaculture, Patuakhali Science and Technology University, Bangladesh

\begin{abstract}
Morphological parameters comprising length-weight relationships (LWRs), sex ratio, condition factor (KF) and allometric growth of paradise threadfin, Polynemus paradiseus from the southern coast of Bangladesh were estimated. A total of 221 specimens were collected with the help of local fishermen ranging size $8.30-13.70 \mathrm{~cm}$ standard length (SL) and $11.64-50.67 \mathrm{~g}$ body weight (BW) during the period of January to October, 2104 . The overall sex ratio of the samples did not reveal significant variation from the expected value of 1:1 (male: female=1:0.99, $\chi^{2}=0.004, P<0.05$ ). Length-frequency distribution revealed a size predominance of males over females, where mean variation of males consistently exceeded that of females throughout the year. The allometric coefficient $b$ of LWR significantly deviated from 3 indicating allometric growth in males and females. The analysis of covariance (ANCOVA) showed significant differences in slope and intercept between the sexes $(P<0.001)$. KF by month in both sexes indicating the fishes were thriving very well in the coast of Bangladesh. This study reports the first findings regarding the LWRs, sex ratio and KF of Polynemus paradiseus in the coastal waters of Bangladesh.
\end{abstract}

Keywords: Length-weight; Size-frequency; Allometric growth; Polynemus paradiseus; Bangladesh

\section{Introduction}

The coastal rivers and estuaries of the southern Bangladesh are categorized by high level of commercial fish catch have direct contribution to the national economy of the country [1-3]. Like other commercial species, paradise threadfin Polynemus paradiseus is one the vital component of estuaries and Bay of Bengal fishery in Bangladesh commonly known as threadfin fish $[4,5]$. This species is available in the Indian subcontinent including Bangladesh, India, Pakistan, Sri Lanka and also reported in Indo-pacific ocean confluence of the Bay of Bengal $[5,6]$. It has an increasingly commercial importance in southern coastal regions of Bangladesh because of its nutritional value and placed as important food item next to importance of Hilsa fishery [5]. In spite of having great economic value, the abundance of fish is declining in Bangladesh due to over exploitation, pollutions, habitat loss and other ecological changes to its habitat [7-11].

Length-weight relationship plays a vital role in the field of fish biology, physiology, ecology, fisheries assessment and fish conservation $[3,12]$. It is considered an essential tool in the studies of fish stock assessment and management of fisheries resources [13,14]. Life-history traits as sex ratio, length-frequency distribution (LFD), length weight relationships (LWRs), and relative-condition factor $(K)$ are generally less known for tropical and subtropical finfish species [15] although this knowledge can be utilized to convert growth-in-length equations to growth-in weight in stock assessment models [16-18], population biomass estimation [16] and fish condition [19]. Few studies have been carried out in different aspects as biology, breeding and nutritional quality of this species but knowledge on length-weight relationships and condition factor of the $P$. paradiseus is not available of this species. Therefore, this article is the first complete and comprehensive description of the LFD, LWRs, sex ratio, $K_{\mathrm{F}}$ and allometric growth of $P$. paradiseus from the coastal waters of Bangladesh in order to provide sufficient data and information for the sustainable management of the species.

\section{Materials and Methods}

The specimens were collected from eight stations of the Payra River located in the southern coastal region of Bangladesh (Figure 1) with the help of fishermen during January-October 2014. Water temperature was also recorded monthly at each sampling. The collected specimens were preserved with ice and transferred to the laboratory prior to analysis. The standard length (SL) of this species was measured to the nearest $1 \mathrm{~cm}$ using a measuring scale, while body weight (BW) was recorded using a digital balance (Shimadzu, EB-430DW, Japan) to 0.01 g accuracy.

Calculations of length-weight data was done separately and also combined using the conventional formula described by as $W=a L^{b}$ where, $W$ is the total weight (expressed in $\mathrm{g}$ ), $\mathrm{L}$ is the standard length (expressed in $\mathrm{cm}$ ), $a$ is a coefficient related to body form and $b$ is an exponent indicating isometric growth when equal to 3 and indicating allometric growth when significantly different from 3 [20]. The parameters $a$ and $b$ were calculated using linear regression analysis equation based on natural log equations of the relationship between BW and SL as follows: $\ln (W)=\ln (a)+b \ln (L)$. Following formula was used for the calculation of condition factors $(K)$ of individual fish species for each month using the expression as $K=\left(W / L^{3}\right) \times 100$ for

*Corresponding author: Muhammad Abu Bakar Siddik, Department of Fisheries Biology and Genetics, Patuakhali Science and Technology University Patuakhali-8602, Bangladesh, Tel: +880 1987-006723; E-mail: siddik@pstu.ac.bd

Received December 25, 2015; Accepted February 26, 2016; Published March 07, 2016

Citation: Chaklader MR, Siddik MAB, Nahar A, Hanif MA, Alam MJ, et al. (2016 Morphometric Parameters and Allometric Growth in Paradise Threadfin Polynemus paradiseus (Linnaeus, 1758) from a Coastal River of Bangladesh. J Aquac Res Development. 7: 417. doi:10.4172/2155-9546.1000417

Copyright: (C) 2016 Chaklader MR, et al. This is an open-access article distributed under the terms of the Creative Commons Attribution License, which permits unrestricted use, distribution, and reproduction in any medium, provided the original author and source are credited. 


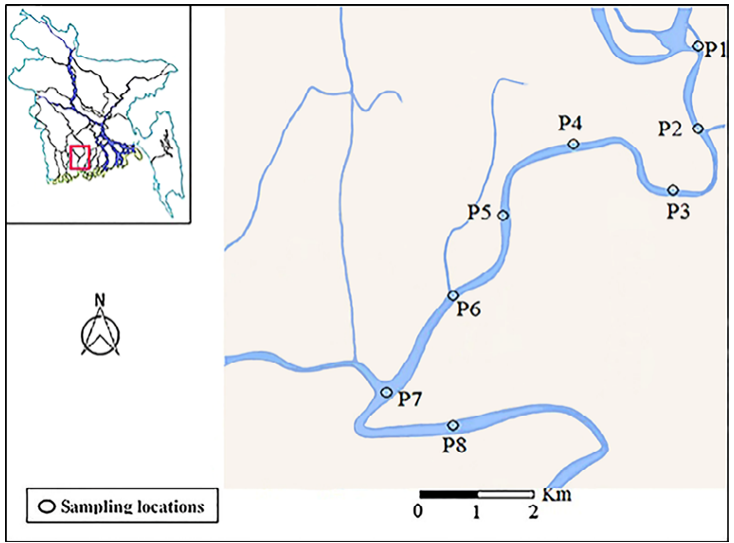

Figure 1: Sampling stations of Polynemus paradiseus in the Payrariver located in the southern coastal region of Bangladesh.

both monthly and in terms of size (SL in $\mathrm{cm}$ ) class.

The form factor $\left(a_{30}\right)$ which was calculated for $P$. paradiseus using the equation given by Froese [21] as: $\mathrm{a}_{3.0}=10^{\log \mathrm{a}-\mathrm{s}(\mathrm{b}-\mathrm{3})}$, where $a$ and $b$ are regression parameters of LWR, and $S$ is the regression slope of $\log$ $a$ vs. $b$. A mean slope $S=-1.358$ Froese [21] was used for estimating the form factor during this study because information on LWRs is not available for this species for estimation of the regression (S) of $\ln a$ vs b. Statistical analysis was performed with SPSS Version 15.0 software package SPSS Inc. 2004.

\section{Results}

A total of 221 specimens were collected of which $50.22 \%$ were males and $49.77 \%$ were females. The overall sex ratio did not show significant difference from the expected value of 1:1 (male: female $=$ 1:0.99, $\left.\chi^{2}=0.004\right)$ (Figure 2).

The SL of the specimen varied between $8.90-13.70 \mathrm{~cm}$ for males and 8.30-13.60 cm for females while BW was ranged between 15.00-50.67 g and $11.64-44.73 \mathrm{~g}$ for males and females, respectively. The SL-frequency distribution showed that the males and females of $P$. paradiseus were not normality distributed $(P<0.001)$ in the southern coastal waters of Bangladesh (Figure 3). The calculated regression parameter $b$ based on relationships between SL and BW indicated negative allometric growth both in males and females for all sample size. There was significant difference observed for both slope $(b)$ and intercept $(a)$ between sexes $(P<0.001)$ (Figures 4 and 5$)$. The estimated allometric coefficients monthly varied between $2.07-3.38$ in males and between 2.22-3.54 in females of $P$. paradiseus during the entire study period. Values of determination coefficients were less than 0.9 , therefore, it was highly insignificant $(\mathrm{P}<0.05)$.

Condition factor $\left(K_{\mathrm{F}}\right)$ of $P$. paradiseus in different months is shown in (Table 1). The $K_{\mathrm{F}}$ value of males was varied from 1.82 to 2.23 and 1.80 to 2.05 in males and females, respectively. The monthly highest $K_{\mathrm{F}}$ was found in April at 9.40 to $12.70 \mathrm{~cm}$ length group with a mean of $2.225 \pm$ 0.053 and lowest in July at 8.90 to $11.80 \mathrm{~cm}$ length group with a mean of $1.830 \pm 0.073$ while the highest $\mathrm{K}_{\mathrm{F}}$ value for females was found in May at 8.30 to $10.30 \mathrm{~cm}$ length group with a mean of $2.054 \pm 0.066$ and lowest in August at 9.20 to $12.70 \mathrm{~cm}$ length group with a mean of $1.802 \pm 0.057$. The highest $K_{\mathrm{F}}$ value for males is higher than that in females in majority of the months except July. (Figure 6) revealed that the overall $K_{\mathrm{F}}$ value of male population was comparatively higher than the female population.
Monthly variations of water temperature along the southern coast of Bangladesh are shown in (Figure 7). The low temperature was observed in January with increasing gradually at beginning of February and remained high from April to October and thereafter started to decrease gradually until December.

\section{Discussion}

Taxonomic studies of this fish have been carried out by Chaklader et al. [5] presented the diversity and standard measurements of male and female fishes. The length-weight relationship, condition factor and

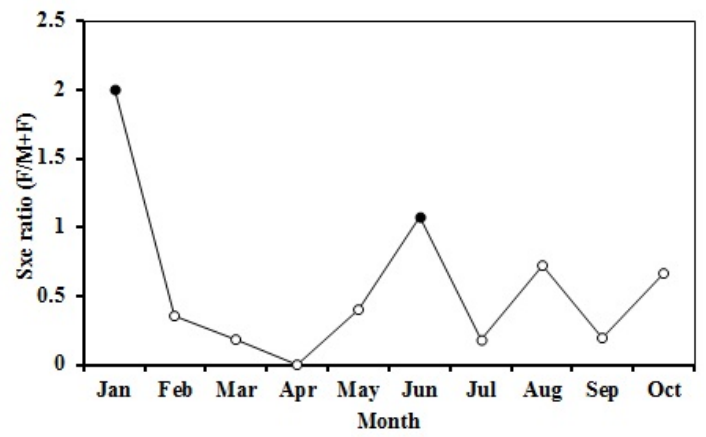

Figure 2: Temporal variation in sex ratio of $P$. paradiseus $(\bullet$ indicates statistically significant difference from 1:1 ratio, non-significant) collected from the Payra river, southern Bangladesh.

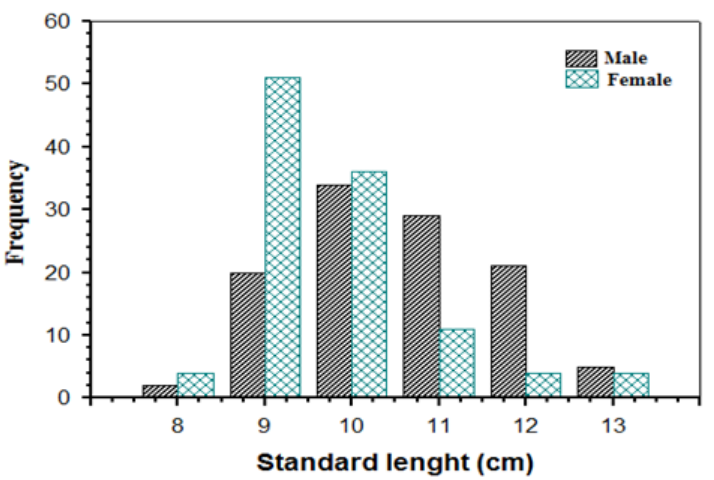

Figure 3: Size-frequency distribution of male and female $P$. paradiseus (Linnaeus, 1758) collected from the Payrariver, southern Bangladesh.

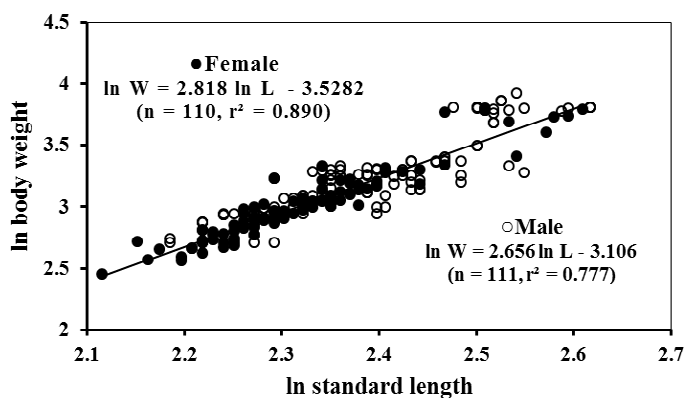

Figure 4: Relationship between log-transformed SL and log-transformed BW for male and female $P$. paradiseus (Linnaeus, 1758) collected from the Payrariver, southern Bangladesh. 


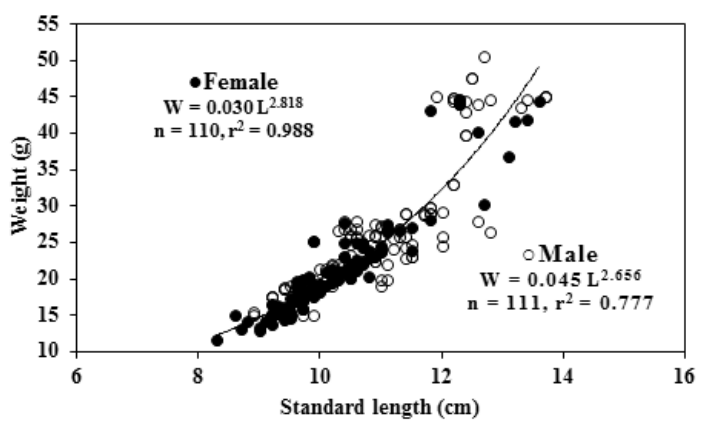

Figure 5: Relationships between SL and BWof male and female $P$. paradiseus (Linnaeus, 1758) collected from the Payrariver, southern Bangladesh.

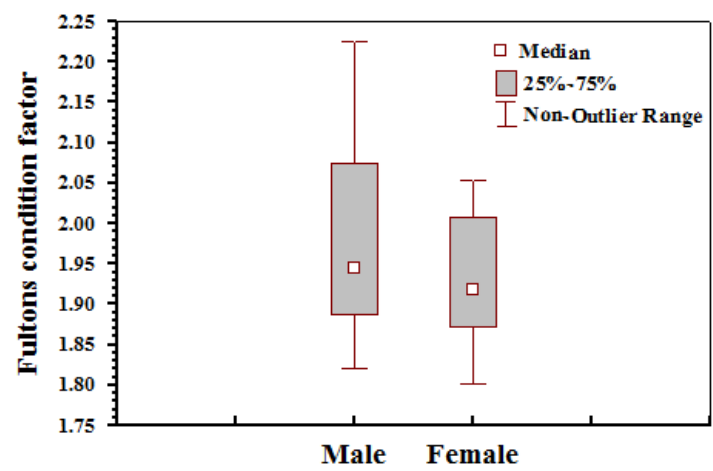

Figure 6: Fulton's condition factor for combined male and female $P$. paradiseus (Linnaeus, 1758) collected from the Payrariver, southern Bangladesh. form factor are recorded for the first time. Female to male ratio vary between 1:1 and 1:1.3 in a typical population reported by Hossain et al. [22]. For most aquatic animals, deviation from a 1:1 sex ratio is not expected but some finfish and prawn populations may shows a strong bias in this ratio [23]. The overall monthly sex ratio was found to be slightly in favor of male and it was revealed that male and female equally presented in most of the months except January, February and August when male was predominant over female but female was predominant male in June and October. In the present study, the overall male and female sex ratio was 1:0.99 in the coastal waters which did not differ significantly from the expected value of $1: 1$. Sex ratio variations may be influenced by reproduction, growth and longevity of a species [24].

The monthly size-frequency distributions indicated that there were more than one size groups found to be present in each month for both sexes. The size predominance in female is a common feature reported

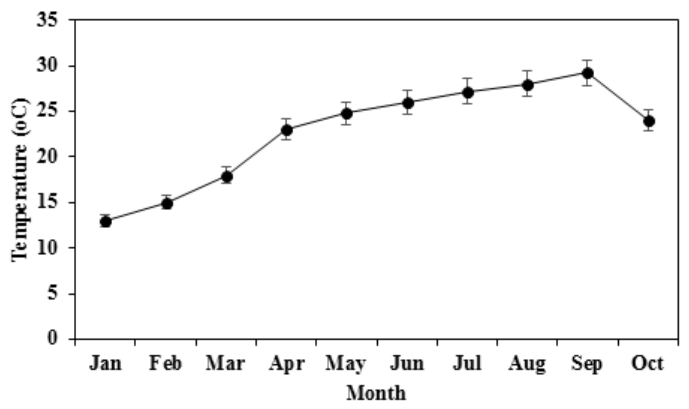

Figure 7: Monthly changes of water temperature in the Payrariver, southern Bangladesh.

\begin{tabular}{|c|c|c|c|c|c|c|c|c|c|c|c|c|c|c|}
\hline \multirow[t]{2}{*}{ Month } & \multirow[t]{2}{*}{ Sex } & \multirow[t]{2}{*}{$\mathbf{n}$} & \multicolumn{2}{|c|}{ Length Characteristics } & \multicolumn{2}{|c|}{ Weight Characteristics } & \multicolumn{5}{|c|}{ Parameters of the LWR } & \multirow[t]{2}{*}{ GT } & \multirow[t]{2}{*}{$a_{3.0}$} & \multirow[t]{2}{*}{$\kappa_{\mathrm{F}}$} \\
\hline & & & $\mathrm{MSL} \pm \mathrm{SE}$ & $S L_{\text {min }}-S L_{\text {max }}$ & $\mathrm{MW} \pm \mathrm{SE}$ & $W_{\min }-W_{\max }$ & $a$ & $\mathrm{LCL}-\mathrm{UCL}$ & $b$ & $\mathrm{LCL}-\mathrm{UCL}$ & $r^{2}$ & & & \\
\hline \multirow[t]{2}{*}{ Jan-14 } & M & 12 & $11.52 \pm 0.28$ & $10.00-12.80$ & $30.97 \pm 3.10$ & $18.81-44.76$ & 0.008 & $0.003-0.156$ & 3.38 & $2.15-4.60$ & 0.79 & $A+$ & 0.026 & 1.969 \\
\hline & $\mathrm{F}$ & 6 & $10.17 \pm 0.25$ & $9.50-10.90$ & $20.38 \pm 1.54$ & $14.92-20.38$ & 0.022 & $0.0002-2.09$ & 2.95 & $0.98-4.92$ & 0.812 & $A+$ & 0.016 & 1.924 \\
\hline \multirow[t]{2}{*}{ Feb } & M & 14 & $11.86 \pm 0.19$ & $10.00-11.00$ & $32.51 \pm 2.54$ & $13.40-23.87$ & 0.012 & $0.0001-2.44$ & 3.18 & $1.03-5.33$ & 0.465 & $A+$ & 0.021 & 1.921 \\
\hline & $\mathrm{F}$ & 11 & $10.00 \pm 0.20$ & $8.80-10.80$ & $18.74 \pm 0.93$ & $13.39-22.66$ & 0.071 & $0.015-0.251$ & 2.42 & $1.87-3.10$ & 0.903 & A- & 0.011 & 1.864 \\
\hline \multirow[t]{2}{*}{ Mar } & M & 10 & $11.48 \pm 0.22$ & $10.40-12.40$ & $29.39 \pm 2.17$ & $21.03-43.00$ & 0.014 & $0.005-0.395$ & 3.13 & $1.76-4.49$ & 0.776 & $A+$ & 0.021 & 1.919 \\
\hline & $\mathrm{F}$ & 12 & $10.08 \pm 0.23$ & $8.70-11.50$ & $19.42 \pm 1.29$ & $13.06-19.42$ & 0.026 & $0.008-0.089$ & 2.86 & $2.33-3.39$ & 0.935 & A- & 0.017 & 1.872 \\
\hline \multirow[t]{2}{*}{ Apr } & M & 11 & $10.68 \pm 0.32$ & $9.40-12.70$ & $28.18 \pm 3.26$ & $18.76-50.67$ & 0.012 & $0.003-0.044$ & 3.28 & $2.71-3.85$ & 0.949 & $A+$ & 0.029 & 2.225 \\
\hline & $\mathrm{F}$ & 11 & $9.95 \pm 0.17$ & $9.00-11.00$ & $18.91 \pm 0.89$ & $12.90-23.66$ & 0.049 & $0.007-0.341$ & 2.59 & $1.74-3.44$ & 0.841 & $1+$ & 0.013 & 1.913 \\
\hline \multirow[t]{2}{*}{ May } & M & 13 & $10.06 \pm 0.19$ & $8.90-11.00$ & $21.32 \pm 1.14$ & $15.00-27.50$ & 0.042 & $0.013-0.132$ & 2.7 & $2.20-3.20$ & 0.927 & $A+$ & 0.017 & 2.075 \\
\hline & $\mathrm{F}$ & 10 & $9.51 \pm 0.19$ & $8.30-10.30$ & $17.92 \pm 1.28$ & $11.64-25.25$ & 0.01 & $0.0007-0.139$ & 3.32 & $2.15-4.50$ & 0.842 & $A+$ & 0.027 & 2.054 \\
\hline \multirow[t]{2}{*}{ Jun } & M & 9 & $9.84 \pm 0.22$ & $8.90-10.90$ & $20.42 \pm 1.12$ & $15.50-27.00$ & 0.126 & $0.014-1.076$ & 2.23 & $1.28-3.17$ & 0.817 & A- & 0.011 & 2.133 \\
\hline & $\mathrm{F}$ & 14 & $9.62 \pm 0.10$ & $9.10-10.30$ & $17.95 \pm 0.73$ & $14.30-25.25$ & 0.021 & $0.0008-0.496$ & 2.98 & $1.58-4.38$ & 0.642 & $A+$ & 0.019 & 2.007 \\
\hline \multirow[t]{2}{*}{ Jul } & M & 10 & $10.30 \pm 0.22$ & $9.70-11.40$ & $19.97 \pm 1.21$ & $15.00-27.00$ & 0.083 & $0.003-2.609$ & 2.35 & $0.87-3.82$ & 0.626 & A- & 0.011 & 1.82 \\
\hline & $\mathrm{F}$ & 12 & $10.44 \pm 0.24$ & $9.40-11.80$ & $23.63 \pm 2.24$ & $14.87-43.17$ & 0.006 & $0.0005-0.071$ & 3.54 & $2.46-4.62$ & 0.843 & $A+$ & 0.032 & 2.018 \\
\hline \multirow[t]{2}{*}{ Aug } & M & 13 & $11.20 \pm 0.33$ & $9.80-13.70$ & $26.70 \pm 2.33$ & $19.00-45.00$ & 0.116 & $0.009-1.437$ & 2.25 & $1.20-3.30$ & 0.688 & A- & 0.011 & 1.882 \\
\hline & $\mathrm{F}$ & 9 & $10.41 \pm 0.38$ & $9.20-12.70$ & $20.48 \pm 1.69$ & $14.95-30.19$ & 0.113 & $0.036-0.343$ & 2.22 & $1.74-2.70$ & 0.944 & A- & 0.01 & 1.802 \\
\hline \multirow[t]{2}{*}{ Sept } & M & 9 & $11.38 \pm 0.41$ & $10.20-13.70$ & $27.88 \pm 2.66$ & $19.00-45.00$ & 0.182 & $0.006-5.223$ & 2.07 & $0.68-3.47$ & 0.638 & A- & 0.01 & 1.888 \\
\hline & $\mathrm{F}$ & 11 & $11.25 \pm 0.45$ & $9.20-13.60$ & $28.33 \pm 3.58$ & $13.78-44.36$ & 0.011 & $0.003-0.034$ & 3.25 & $2.76-3.74$ & 0.961 & $A+$ & 0.024 & 1.879 \\
\hline \multirow[t]{2}{*}{ Oct } & M & 10 & $11.44 \pm 0.45$ & $9.20-13.70$ & $31.84 \pm 3.70$ & $17.67-47.65$ & 0.031 & $0.004-0.225$ & 2.85 & $2.01-3.69$ & 0.885 & $A+$ & 0.019 & 2.054 \\
\hline & $\mathrm{F}$ & 14 & $10.73 \pm 0.37$ & $8.60-13.40$ & $25.07 \pm 2.52$ & $15.14-44.73$ & 0.019 & $0.014-0.162$ & 2.63 & $2.11-3.15$ & 0.91 & A- & 0.006 & 1.969 \\
\hline \multirow[t]{3}{*}{ Overall } & M & 111 & $11.00 \pm 0.11$ & $8.90-13.70$ & $27.09 \pm 0.87$ & $15.00-50.67$ & 0.045 & $0.023-0.086$ & 2.67 & $2.39-2.93$ & 0.777 & A- & 0.016 & 1.987 \\
\hline & $\mathrm{F}$ & 110 & $10.21 \pm 0.10$ & $8.30-13.60$ & $21.19 \pm 0.67$ & $11.64-44.73$ & 0.03 & $0.019-0.045$ & 2.82 & $2.63-3.01$ & 0.89 & A- & 0.017 & 1.935 \\
\hline & B & 221 & $10.61 \pm 0.07$ & $8.30-13.70$ & $24.16 \pm 0.58$ & $11.64-50.67$ & 0.032 & $0.022-0.045$ & 2.8 & $2.64-2.96$ & 0.849 & A- & 0.017 & 1.961 \\
\hline
\end{tabular}

Table 1: Monthly descriptive statistics, estimated parameters of length-weight relationships, Fulton Condition Factor (KF) and Form factor (a3.0) for $P$. paradiseus (Linnaeus, 1758 ) along the southern coast of Bangladesh. 
by several studies [25]. Numerous factors, such as physiological changes influenced by temperature change, feeding regime and reproductive cycle might be responsible for size difference between male and female [26]. Besides, traditional fishers used numerous types of fishing gear with various mesh sizes leading to the selectivity of target species which may greatly influence the size distribution of the individuals caught resulting in highly biased estimations of the various population parameters including the maximum size [22].

In this study, the $b$ values for male, female and combined gender of $P$. paradiseus were found as $2.66,2.82$ and 2.80, respectively indicating negative allometric growth of $P$. paradiseus in the coastal waters i.e., fish gets slimmer with increasing length [27]. It is widely recognized that a number of factors including growth phase, sex, seasons, food (quantity, quality and size), stage of maturity and health and general fish condition, preservation techniques and differences in the observed length ranges of the specimen caught are known to influence the length-weight relationship in fish [28] all of which were not accounted in the present study.

Condition factor is an index reflecting interactions between biotic and abiotic factors in the physiological condition of the fishes indicating the well-being of the population during various life cycle stages [21]. In the present study, the $K_{\mathrm{F}}$ values of $P$. paradiseus was highest in April for males and May for females respectively, whilst the lowest was in July for males and August for females (Table 1). The monthly mean $K_{\mathrm{F}}$ values were always above 1 and no major variation was found in different length groups. Le Cren [29], reported that $K_{\mathrm{F}}$ values greater than 1 indicates good general condition of the fish whereas values less than 1 denotes the reverse condition. It is clearly indicated that the growth pattern of the fish was ideal in the study areas. In general, the seasonal cycle is related with the condition of fishes suggested a relationship with gonadal development. Since the paradise threadfin spawns in March to June [5], the highest $K_{\mathrm{F}}$ was found that month for both male and female [30] pointed out that the condition factor was constant during the pre-spawning period, decreased in the period of spawning and was lowest immediately after spawning in case of silver hatchet chela, Chela cachius (Hamilton 1822). $K_{\mathrm{F}}$ values are generally influenced by the changing of seasons, amount of food supply, and maturity of gonads [31]. Fluctuation of water temperature occurred in all month and optimum range $\left(20-25^{\circ} \mathrm{C}\right)$ found from April to July during the experimental period shown in (Figure 6). $\mathrm{K}_{\mathrm{F}}$ is strongly influence by both biotic and a biotic environmental conditions and can be used as an index to assess the status of the aquatic ecosystem in which fish live [32]. Several studies stated that the water temperature has considerable importance for controlling spawning of fish [30]. However, no references dealing with the condition factors of the $P$. paradiseus are available in the coastal waters, preventing the comparison with previous results from the same population.

There are few studies dealing with form factor of fishes available in Bangladeshi waters [33]. Nevertheless, reference concerning the form factor of this species is not available as it is the first study of this species. Therefore, the study provides basic information on some morphological parameters including the sex ratio, LFD, LWRs, condition factor and growth type of $P$. paradiseus in the southern coastal waters which should be useful for the sustainable management of finfish fishery not only in southern Bangladesh but its whole geographic locations. Yet, more detailed studies should be conducted to answer several questions about body-size range and the spawning periodicity of this finfish fishery.

\section{References}

1. Hanif M, Siddik M, Chaklader M (2015) Fish diversity in the southern coastal waters of Bangladesh: present status, threats and conservation perspectives. Croatian Journal of Fisheries 73: 251-274.

2. Sharker M, Mahmud S, Siddik M, Alam M, Alam M, et al. (2015) Livelihood status of hilsha fishers around Mohipur fish landing site, Bangladesh. World Journal of Fish and Marine Sciences 7: 77-81.

3. Siddik M, Hanif M, Chaklader M, Nahar A, Mahmud S, et al. (2016) Fishery biology of gangetic whiting Sillaginopsis panijus (Hamilton, 1822) endemic to Ganges delta, Bangladesh. Egyptian Journal of Aquatic Research 41: 307-313.

4. Hanif M, Siddik M, Chaklader M, Mahmud S, Nahar A (2015) Biodiversity and conservation of threatened freshwater fishes in Sandha River, South West Bangladesh. World Applied Sciences Journal 33: 1497-1510.

5. Chaklader M, Siddik M, Nahar A (2015) Taxonomic diversity of paradise threadfin Polynemus paradiseus (Linnaeus, 1758) inhabiting southern coastal rivers in Bangladesh. Sains Malaysiana 44: 1241-1248.

6. Siddik M, Nahar A, Ahamed F, Hossain M (2014) Over-wintering growth performance of mixed-sex and mono-sex Nile tilapia Oreochromis niloticus in north-eastern Bangladesh. Croatian Journal of Fisheries 72: 70-76.

7. Hoq M (2007) An analysis of fisheries exploitation and management practices in Sundarbans mangrove ecosystem, Bangladesh. Ocean and Coastal Management 50: 411-427.

8. IUCN (2000) The world conservation union, Red book of threatened fishes of Bangladesh, Dhaka, Bangladesh, IUCN.

9. Siddik M, Nahar A, Ahamed F, Masood Z, Hossain M (2013) Conservation of critically endangered olive barb Puntius sarana (Hamilton, 1822) through artificial propagation. Our nature 11: 96-104.

10. Chaklader M, Nahar A, Siddik M, Sharker R (2014) Feeding habits and die composition of Asian Catfish Mystus vittatus (Bloch, 1794) in shallow wate of an impacted coastal habitat. World Journal of Fish and Marine Sciences 6 : 551-556.

11. Sharker M, Siddik M, Nahar A, Shahjahan M, Faroque A (2015) Genetic differentiation of wild and hatchery populations of Indian major carp Cirrhinus cirrhosis in Bangladesh. Journal of Environmental Biology 36:1223-1227.

12. Mustac B, Sinovcic G (2010) Morphometric and meristic parameters of sardine (Sardina pilchardus, Walbaum, 1792) in the Zadar fishing area. Croatian Journal of Fisheries 68: 27-43.

13. Al-Beak A, Ghoneim, El-Dakar A, Salem M (2015) Population Dynamic and Stock Assesment of White Seabream Diplodus sargus (Linnaeus, 1758) in the Coast of North Sinai. Fish Aquac J 6:152. doi:10.4172/2150-3508.1000152.

14. Rodríguez-Romero J, Palacios-Salgado D, López-Martínez J, Hernández Vázquez S, Velázquez-Abunader J, et al (2009) The length-weight relationship parameters of demersal fish species off the western coast of Baja California Sur, Mexico. J Appl Ichthyol 25: 114-116.

15. Ecoutin J, Albaret J, Trape S (2005) Length-weight relationships for fish populations of a relatively undisturbed tropical estuary: The Gambia. Fisheries Research 72: 347-351.

16. Qambrani G, Soomro A, Palh Z, Baloch W, Tabasum S, et al.. (2016) Reproductive Biology of Glossogobius giuris (Hamilton), in Manchar Lake Sindh, Pakistan. J Aquac Res Development 7: 392.

17. Morato T, Afonso P, Lourinho P, Barreiros J, Santos R, et al. (2001) Lengthweight relationships for 21 coastal fish species of the Azores, north-eastern Atlantic. Fisheries Research 50: 297-302.

18. Ozaydin O, Taskavak E (2006) Length-weight relationships for 47 fish species from Izmir Bay (eastern Aegean Sea, Turkey). Acta Adriatica 47: 211.

19. Chatterji A, Pati S, Dash B (2015) A Study on the Growth of Juveniles of Tige Prawn, Penaeus monodon (Fabricius) Under Different Photoperiods. J Aquac Res Development 6: 385

20. Simon K, Mazlan A (2008) Length-weight and length-length relationships of archer and puffer fish species. The Open Fish Science Journal 1:19-22.

21. Froese $R$ (2006) Cube law, condition factor and weight-length relationships: history, meta-analysis and recommendations. J Appl Ichthyol 22: 241-253.

22. Hossain M, Khatun M, Jasmine S, Rahman M, Jewel M, et al. (2013) Life 
Citation: Chaklader MR, Siddik MAB, Nahar A, Hanif MA, Alam MJ, et al. (2016) Morphometric Parameters and Allometric Growth in Paradise Threadfin Polynemus paradiseus (Linnaeus, 1758) from a Coastal River of Bangladesh. J Aquac Res Development. 7: 417. doi:10.4172/2155-9546.1000417

Page 5 of 5

history traits of the threatened freshwater fish Cirrhinus reba (Hamilton 1822) in the Ganges River, Bangladesh. Sains Malaysiana 42: 1219-1229.

23. Hossain M, Sharmin J, Rahman M (2015) Biological Aspects of the critically endangered fish, Labeo boga in the Ganges River, Northwestern Bangladesh. Sains Malaysiana 44: 31-40.

24. Chilari A, Thessalou-Legaki M, Petrakis G (2005) Population structure and reproduction of the deep-water shrimp Plesionika martia (Decapoda: Pandalidae) from the eastern Ionian Sea. J Crustacean Biol 25: 233-241.

25. Ohtomi J, Yamamoto S, Koshio S (1998) Ovarian maturation and spawning of the deep-water mud shrimp Solenocera melantho De Man, (Decapoda, Penaeoidea, Solenoceridae) in Kagoshima Bay, southern Japan. Crustaceana 71: $672-685$

26. Newman S, Cappo M, Williams D (2000) Age, growth, mortality rates and corresponding yield estimates using otoliths of the tropical red snappers, Lutjanus erythropterus, L. malabaricus and $L$. sebae, from the central Great Barrier Reef. Fisheries Research 48:1-14.

27. Jobling M (2008) Environmental factors and rates of development and growth, Oxford: Blackwell Publishing, England.
28. Koutrakis E, Tsikliras A (2003) Length-weight relationships of fishes from three northern Aegean estuarine systems (Greece). J Appl Ichthyol 19: 258-260.

29. Le Cren $E$ (1951) The length-weight relationship and seasonal cycle in gonad weight and condition in the perch (Perca fluviatilis). The Journal of Animal Ecology 20: 201-219.

30. Ahamed F, Ohtomi J (2012) Growth patterns and longevity of the pandalid shrimp Plesionika izumiae (Decapoda: Caridea). J Crustacean Biol 32 733-740.

31. Iqbal K, Masuda Y, Suzuki H, Shinomiya A (2006) Age and growth of the Japanese silver-biddy, Gerres equulus, in western Kyushu, Japan. Fisheries research 77: 45-52.

32. Anene A (2005) Condition factor of four Cichlid species of a man-made lake in Imo State, Southeastern Nigeria. Turkish Journal of Fisheries and Aquatic Sciences 5 : 43-47.

33. Sani R, Gupta B, Sarkar U, Pandey A, Dubey V, et al. (2010) Length-weight relationships of 14 Indian freshwater fish species from the Betwa (Yamuna River tributary) and Gomti (Ganga River tributary) rivers. J Appl Ichthyol 26: 456-459. 